ADVANCE RESEARCH JOURNAL OF SOCIAL SCIENCE
$\begin{gathered}\text { A CASE } \\ \text { STUDY }\end{gathered}$ $\begin{array}{cc}\text { volume } 9 \mid \text { Issue } 1 \mid \text { June, 2018 | 130-135 qe ISSN-2231-6418 } \\ \text { DOI: 10.15740/HAS/ARJSS/9.1/130-135 } & \text { visit us : www.researchjournal.co.in }\end{array}$

\title{
Struggle of the linguistic minorities and the formation of Pattom Colony
}

C.L. Vimal Kumar

Department of History, K.N.M. Government Arts and Science College, Kanjiramkulam, Thiruvananthapuram (Kerala) India

\section{ARTICLE INFO :}

Received : 07.03 .2018

Accepted : 28.05.2018

\section{KEY WORDS :}

Kuthakapattam, Annas, Prathidwani, Pattayam, Blocks, Pilot colony

\section{HOW TO CITE THIS ARTICLE :}

Vimal Kumar, C.L. (2018). Struggle of the linguistic minorities and the formation of Pattom Colony. Adv. Res. J. Soc. Sci., 9 (1) : 130-135, DOI: 10.15740/HAS/ ARJSS/9.1/130-135.

Copyright@2018 : Hind Agri -

Horticultural Society

*Author for correspondence

\begin{abstract}
Land has many uses but its availability is limited. During the early 1940s extensive food shortages occurred throughout Travancore. As a result, the government opened forestlands on an emergency basis for food cultivation and in 1941 granted exclusive cultivation rights known as 'Kuthakapattam' was given (cultivation on a short-term lease) in state forest areas. Soon after independence, India decided to re-organize state boundaries on a linguistic basis. The post Independence State reorganization period witnessed Tamil-Malayali dispute for control of the High Ranges. The Government of Travancore-Cochin initiated settlement programmes in the High Range areas in order to alter the regional linguistic balance. Pattom colony, which was sponsored by Pattom Thanupillai ministry, as a part of High Range colonization scheme. It led to forest encroachment, deforestation, soil erosion, migration, conflict over control of land and labour struggle and identity crisis etc.
\end{abstract}

